УДК: 37.041

Солдатенко Микола Миколайович, доктор педагогічних наук, завідувач відділу теорії та історії педагогічної майстерності Інституту педагогічної освіти і освіти дорослих НАПН України, м. Київ

\title{
ТЕОРЕТИЧНІ АСПЕКТИ ПІЗНАВАЛЬНОЇ ДІЯЛЬНОСТІ
}

\section{Анотація}

У статті аналізуються деякі особливості пізнавального процесу, механізми його взаємодії з практичною діяльністю і комунікацією. Розглядається навчальне і наукове пізнання, процеси розвитку знання i «виробництва» наукового знання. Пізнавальна діяльність розглядається як процес отримання нового знання через механізми сприйняття інформації, iї осмислення, запам'ятовування і використання знань у практичній діяльності. Аналізується характер взаємодії нового знання як з окремими компонентами соціальної реальності, так і з тим знанням, яке йому передувало.

Ключові слова: пізнання, пізнавальний процес, інформація, наукове знання.

Зміни, які нині відбуваються у нашому суспільстві, настільки великі, що цілком можна говорити про принципово нову глобальну проблему сучасної цивілізації проблему, яка належно ще не усвідомлена і поки що не зайняла свого місця в освіті. Мова йде про те, що зараз відбувається перехід від постіндустріального до інформаційного розвитку суспільства. Віртуальний аспект буття все помітніше домінує над аспектом фундаментальним, причому цей перелом охоплює всю інтелектуальну сферу. Інформація стає визначальним фактором, який прискорює як процеси глобалізації й інтернаціоналізації, так і всі суспільні інституції - розвиток науки, техніки, освіти, культури. Тому освітній процес повинен стати джерелом реального життєвого досвіду учнів і досвіду виживання у світі інформації, кількість якої постійно і швидко зростає.

Отже, пізнання як процес цілеспрямованого активного відображення об' єктивного світу у свідомості людей, нині ускладнюється. Інформатизація суспільства проникає не 
лише в бізнес, виробництво, сферу обслуговування, а й у побут, освіту, стиль життя. На думку деяких дослідників, сама природа економіки інформаційного суспільства надає пріоритет не державі, а особистості. Тому можна без перебільшення стверджувати, що вона значно змінила і цінності людей, моделі їх поведінки, їх переорієнтацію 3 матеріальних цінностей на цінності самореалізації. Про це переконливо свідчать i численні результати анкетування, опитування викладачів, студентів і учнів, проведеного нами та іншими дослідниками. Відомо, що оволодіння знаннями - складний процес, який включає в себе систему навчально-пізнавальних дій, кожна 3 яких виводить на більш високий рівень засвоєння матеріалу, що вивчається, формування і вдосконалення практичних умінь і навичок. Якщо побудувати модель пізнавальної діяльності, то вона повинна включати виконання низки таких дій: розпізнавання, сприйняття й осмислення інформації, запам'ятовування, відбору та зберігання, уміння використати засвоєні знання на практиці.

Відзначимо, що лише здійснення повного циклу пізнавальних дій гарантує міцне засвоєння і розуміння навчального матеріалу. Головним недоліком у навчанні і практиці є невміння використати отримані знання в практичній діяльності, адже для повного відтворення потрібного знання (у теоретичному плані - перш за все) завжди можна скористатися посібниками, довідниками, інструкціями і т. п. Передумовою ефективності організації навчально-пізнавальних дій може бути залучення студентів (чи учнів) до активного пізнавального процесу, адже ефективність будь-якої діяльності багато в чому залежить від мотивації суб' єкта і його відношення до неї. Водночас виникає необхідність використання низки психолого-педагогічних прийомів, основою яких є створення таких дидактичних умов, які викликають у суб'єкта пізнання переживання внутрішніх протиріч між знанням і незнанням, пізнавальними задачами і недостатністю знань для їх вирішення, між наявним і необхідним рівнями наукової підготовки.

У нових умовах знання взагалі, і наукове в тому числі, не лише відіграє принципово нову роль у відтворенні соціальних і культурних відносин, але змінює й сам характер його взаємодії 3 іншими компонентами соціальної реальності. значно змінюється і те, що ми називаємо «знання», «пізнання», змінюються уявлення про раціональне знання, питання взаємовідносин пізнання, діяльності і комунікації, явного і 
неявного знання, роль пізнавальної рефлексії, питання про різноманітність видів і форм знання i , нарешті, низка питань, пов’язаних із пізнанням соціально-культурних феноменів сучасного суспільства.

Відомо, що три види діяльності - зовнішня практична діяльність, процеси пізнання і комунікації у вихідному пункті процесу формування свідомості діють взаємопов'язано й одночасно [5]. Згодом, на стадії сформованості свідомості, безперервний зв’язок практичної діяльності, пізнання і комунікації розривається. Звичайно, не всяке пізнання прямо пов'язане 3 виявленням способів практичного перетворення об'єкта, хоча глибокий внутрішній зв’язок пізнання і практичної діяльності зберігається на всіх рівнях знання. Очевидним є і той факт, що розвинений процес пізнання зовсім не співпадає 3 актом комунікації. Останній виділяється в самостійну сферу діяльності, яка управляється особливими законами. Для прикладу: коли я міркую «про себе», то чимало звичних для мене й очевидних ходів думки я пропускаю, ніби «проковтую», низку передумов не формулюю явно, деякі дослідницькі прийоми здійснюю в «згорнутому» вигляді і т. п. При цьому повідомлення результатів моєї пізнавальної діяльності передбачає експліцитне формування значної частини того, що мало місце в неявному вигляді (хоча i не всього, бо можливість комунікації обов’язково пов'язана з наявністю цілої низки передумов у різних індивідів), а також врахування точки зору співбесідника, рівня його знань у даній галузі і т. п.

Разом 3 тим, будь-яка пізнавальна діяльність - якою б не була іiі суб'єктивна форма, носить соціально-опосередкований характер, а, отже, здійснюється не лише «для мене», але й для інших людей, включених у дану систему соціально-культурних нормативів. Це стосується і таких пізнавальних ідей, які виникають у свідомості людини в словесно неопосередкованій формі, адже поряд із вербальним спілкуванням існують $\mathrm{i}$ більш прості рівні людської комунікації, наприклад, такий iï основний i, разом 3 тим, початковий як сама предметна діяльність. Водночас саме в процесі комунікації в найбільш явному і розгорнутому вигляді виступають ті внутрішні норми, які управляють пізнавальним процесом [2].

Саме $з$ цієї причини, коли мова йде про теоретико-пізнавальне дослідження, тобто виявлення певних, потрібних нам знань, то найбільш підходящим матеріалом для аналізу 
можуть бути процеси і засоби саме комунікативної діяльності, у яких пізнання отримує опредметнене, об'єктивне вираження, а не самі собою взяті явища свідомості, у яких ці предмети, смисли виступають ніби уже в «перетвореній формі», у «згорнутому» вигляді і не завжди є достатньо очевидними для самого суб'єкта.

Нас тут, звичайно ж, цікавить, у першу чергу, аспект опредмечування, об'єктивування, загальні норми, еталони «виробництва» й оцінювання отримуваних знань, що $є$ надзвичайно важливим для забезпечення ефективності педагогічного процесу на всіх його рівнях. Зауважимо, що процес передавання знань передбачає їх об’єктивацію не лише у вигляді текстів чи висловлювань, а й у формі створених людиною предметів, яким притаманний соціально-культурний смисл. Саме тому предметна діяльність будь-якого суб' єкта завжди аналізується в єдності з пізнавальними і комунікативними функціями як основа цілісного процесу пізнавальної діяльності.

Що ж стосується реалій розвитку наукового знання, то можна відзначити, що якою б значною не була роль передбачення нових фактів у теоретичному плані, усе ж набагато важливішим є їх практичне спостереження. Надзвичайно значимі нові наукові факти, іноді парадоксальні, завдяки яким відбувається потрясіння «храму науки», завжди вносили свіжий потік не лише в пізнавальну, а й практичну діяльність цілої епохи. Для прикладу достатньо назвати лише деякі з них: відкриття електромагнітної індукції, розробка теорії відносності, досягнення сучасного матеріалознавства, розвиток електронної і космічної техніки останніх десятиріч тощо.

Отже, питання про розвиток знання переростає в питання про розвиток його у ході поняттєво-концептуалізуючої і тлумачної діяльності, яка здійснюється як усередині тих систем, де це знання раціонально «організовується», так і в процесах, які протікають між системами. Найбільш жорстко-формальним способом організації знання є дедуктивний. На перший погляд здається, що цей спосіб виключає можливість одержання певного приросту знання. Цікавим все ж є той факт, що є чимало різних доказів обов'язкового прирощення інформативності навіть при формально-логічних процедурах. Досить симптоматичними свідченнями 3 приводу цього можуть бути думки тих, хто сам, без сумніву, належить до числа видатних творчих талантів, які проявлялись разом 3 тим і в пізнанні самого себе (А. Ейнштейн, М. Планк, Анрі Пуанкаре, Жак Адамар та ін.). Ось 
як про це висловився видатний математик А. Пуанкаре, який володів досить сильною методологічною рефлексією: навіть «коли я повторюю засвоєне доведення... я щонайменше самостійно створюю його кожного разу, коли мені доводиться його повторювати» (Пуанкаре А. Математическое творчество // Пуанкаре А. О науке. - М., 1983. - C. 311).

Як учений учень чи студент, включений у процес «виробництва» наукового знання, одночасно є і частковим суб'єктом науки, культури, виробництва. Оскільки індивід за допомогою власних пізнавальних засобів отримує нове знання, тобто деякі відомості про об’єкт, які ще не мають загальновизнаної раціональної форми, то ми цілком можемо трактувати його діяльність як індивідуальний, особистісний компонент пізнавальної діяльності соціального суб’єкта, а отримані ним результати як особисте знання [3]. Цей компонент значно забезпечує i приріст, і ефективне використання знання. Значною мірою - бо при цьому не можна не рахуватись 3 тим приростом соціалізованого знання, яке уже є як науковий здобуток у даний момент. Можливо, що частина такого (наявного вже) знання $\epsilon$ «прихованою» в певних теоретичних конструкціях і його лише слід «проявити». У цьому випадку новизна такого нового знання є дещо відносною.

Наукове знання успішно розвивається лише тією мірою, якою вчений постає як «єдність протилежностей» - індивідуального і соціального, одиничного і загального. Саме тому раціональне й інтуїтивне є не двома принципово різними галузями знання $\mathrm{i}$ формами пізнання, а двома етапами єдиного пізнавального процесу. Відносна ж границя переходу особистого знання в соціальне є рухливою, оскільки і засоби трансляції знання, і форми його соціального буття постійно змінюються в практиці спілкування людей, забезпечуються розширенням загального інформаційного поля, сфери культури.

Зазначимо, що незнання не лише передує знанню, а й містить в собі можливість переходу до нього, представляючи собою певну фазу в його розвитку. Усвідомлення суті незнання означає виникнення питання (постановка задачі), що і веде до становлення нового елемента знання як виразу певної активності суб'єкта пізнавальної діяльності, яка проявляється у цілеспрямованому переборюванні труднощів [5 ]. Ці питання виникають у зв’язку з протиріччями руху думки, коли джерело численних запитань знаходиться в 
переході від знання закону до його використання, від науки і техніки до практичної діяльності.

Людина завжди живе у світі інформації, і сама ії сутність, психіка - не що інше, як надзвичайно складна інформаційна система, яка приймає інформацію із зовнішнього світу, переробляючи і накопичуючи іï у своїй пам'яті у вигляді знань [1]. Водночас у людини генерується нова інформація, яка виступає як регулятивний фактор у різних видах іiї діяльності і життєвої активності. Зокрема, за допомогою тих чи інших засобів ця інформація екстеріоризується, об'єктивується й, отже, стає доступною для сприйняття тими суб' єктами чи аудиторією, для яких вона передбачалась.

Що ж до об’єктивації знань, то у цьому процесі універсальним засобом виступають різного роду знакові системи, наприклад, писемна мова. Читаючи, наприклад, ці рядки, ми фактично сприймаємо закодовану нечисленними алфавітними знаками мову, лексичні засоби природної мови, слова, які, у свою чергу, є знаками деякої нелінгвістичної реальності. У кінці довгого і складного ланцюга психічних перетворень в нашому мозку виникає деяке когнітивне утворення, яке ми називаємо знаннями. Людські знання можуть бути інструментом перетворення світу й одночасно певним щаблем для досягнення нового, більш високого знання. Слід пам'ятати, що це $є$ необхідною умовою формування «знання про незнання», на подолання якого фактично і спрямована пізнавальна діяльність.

Виходячи з цього, повинна бути зрозумілою та винятково важлива роль знань у прогресі людства і зрозумілим прагнення до вдосконалення пізнавальної діяльності і форми фіксації отриманого знання [4]. Про значимість цих процесів свідчить серйозна увага, яка їм приділялась протягом кількох тисячоліть; не є винятком, звичайно, й сьогодення, коли відбувається надзвичайно активне удосконалення як пізнавальної діяльності, так і винайдення принципово нових форм фіксації здобутих знань [там само]. Про це свідчить стрімкий розвиток інформаційних i навчальних технологій, їх проникнення в усі сфери життя сучасного суспільства, коли останнє стало глобальною тенденцією світового розвитку.

На відміну від інформації, яка відображає зміст гуманітарних видів знань (наприклад, філософського, лінгвістичного, історичного, педагогічного і т. п.), де 
вербальні знакові системи, текст є домінуючими й адекватно фіксують цей зміст у відповідній формі, у випадку науково-технічного знання текст, не дивлячись на його важливість, має чимало конкурентів, які «спеціалізуються» на передаванні саме цього знання. У випадку фіксації науково-технічного знання часто найбільш суттєва інформація передається позатекстовими формами (креслення, схема, технічний рисунок, технічна фотографія, формула, таблиця, графіки, діаграми, піктограми та ін.), текст же при цьому виконує сполучну функцію, доповнюючи, інтерпретуючи або ж здійснюючи підготовку розуміння цих позатекстових форм пред’явлення інформації.

Отже, щоб суб’ єкт учіння міг найбільш легко, повно і зрозуміло засвоїти потрібну йому інформацію, необхідно подбати про вдосконалення форм пред’явлення останньої. Адже інформація потрібна не сама собою, вона не самоціль, а $є$ лише засобом досягнення мети, і в більшості випадків знаходиться за ії межами. Інформація завжди адресується людині, яка має їі сприйняти, зрозуміти, осмислити, зробити висновки й отримані знання впровадити в практику, або ж, грунтуючись на них, продовжити процес вироблення нових знань. Це викликає специфічно «людські» вимоги щодо забезпечення оптимальних умов сприйняття і розуміння інформації - тобто вимоги, забезпечення яких передбачає вивчення психологічних особливостей і можливостей суб'єкта пізнавальної діяльності щодо прийому, зберігання, переробки і вироблення нової інформації.

Аналіз пізнання включає в себе дослідження відносин суб'єкта й об' єкта, того, хто пізнає, і того, на кого (що) спрямоване пізнання. Якщо, наприклад, я стверджую, що знаю щось про той чи інший предмет моїх спостережень, то цим самим передбачається одночасне усвідомлення мною таких моментів: по-перше, того, що моє знання свідчить про існування деякого об'єкта, який не співпадає з цим знанням, тобто знаходиться поза ним; по-друге, що це знання належить мені, що процес пізнання я здійснюю як суб'єкт; по-третє, що я претендую на відображенні в знанні дійсного, реального стану справ і можу підтвердити цю претензію шляхом тої чи іншої процедури обгрунтування знання.

Зазначимо, що процес передавання знання передбачає об' єктивацію останнього не лише у вигляді текстів або висловлювань, але й у формі створених людиною предметів, які мають певний соціально-культурний смисл. Тому теорія пізнання аналізує предметну діяльність в єдності іiі з пізнавальними, комунікативними і практично перетворюючими 
функціями як основу всього пізнавального процесу. Разом з тим теорія пізнання не може не враховувати і данність предметних смислів у свідомості хоча б тому, що об'єктивна предметна діяльність, яка відповідає деяким із глибинних пізнавальних еталонів (наприклад, перцептивним об' єкт-гіпотезам), до цього часу є недостатньо дослідженою в науковому плані, а, отже, ми не володіємо іншими, окрім даних свідомості, способами виявлення змісту цих смислів. Саме тому вихідний пункт аналізу знання розуміють не як вивчення відношення індивідуального суб'єкта (будь то організм чи свідомість) до об'єкта, який пізнається, а як дослідження функціонування i розвитку систем колективної міжсуб' єктної діяльності.

В основі останньої лежить практичне перетворення зовнішніх об'єктів. Сам же індивід як суб’єкт свідомості і пізнання існує лише остільки, оскільки він виступає як агент цієї діяльності, тобто включається в певну систему відношень до інших суб' єктів і оволодіває соціальними способами діяльності, об'єктивованими в предметахпосередниках. У цьому розумінні можна говорити, що специфічне людське пізнання та їі суб'єкт - це «штучні» продукти. Тут мається на увазі та принципова з точки зору гносеології обставина, що пізнавальний процес, «виробництво» знання передбачають розрив із природним відношенням об'єкта пізнання до зовнішнього середовища i використання таких еталонів, які мають соціально-культурний (і саме в цьому розумінні «штучний») характер.

Зрозуміло, що в різних соціально-культурних умовах предметні смисли, які втілюються в зовнішній діяльності людини, а потім і в суб' єктивному світі свідомості будуть дещо різними. Їх зміст визначається не тільки світом реальних об'єктів, а й ступенем їх засвоєності суспільною практикою, яка постійно розвивається. Соціальнокультурна обумовленість процесів пізнання, звичайно, не заперечує, що суб'єктивний світ кожного індивіда є неповторним і своєрідним, а, отже, процес інтеріоризації знань, у ході якого і формується суб'єктивне світопізнання, кожного разу відбувається в умовах, які не повторюються. Саме в таких умовах має місце процес формування унікальних індивідуальних рис особистості, у ході засвоєння нею загальних смислових структур, які становлять основу пізнавальної діяльності людини. Отже, помилково було б думати, що культура мислення формується ніби сама собою, під час навчання в школі чи 
професійної підготовки у вищих навчальних закладах. Без значних зусиль з боку психологічних і педагогічних наук, спрямованих на розвиток культури навчальнопізнавальної діяльності, особливо такої ऑiі складової як самостійна навчальнопізнавальна діяльність, малоефективною буде не лише професійна підготовка, a, відповідно, й творча діяльність у галузі науки, техніки, виробництва.

\section{Список використаних джерел}

1. Антонов A. В. Информация: восприятие и понимание. - Киев: Наукова думка, 1988. - 184 c.

2. Брушлинский A. В. Субъект: мышление, учение, воображение. - М.: НПО «МОДЭК», 1996. - 392 с.

3. Заволока Н. Г. Методологические и логико-гносеологические основы учебнопознавательного процесса. - К.: Вища школа, 1986. - 228 с.

4. Моисеев А. И. Звуки и буквы, буквы и цифры. Кн. для внеклас. чтения учащихся 8-10 кл. сред. шк. - М.: Просвещение, 1987. - 192 с.

5. Теория познания. В 4 т. Т. 2. Социально-культурная природа познания / $\mathrm{AH}$ СССР. Ин-т философии; Под. ред. В. А. Лекторского, Т. И. Ойзермана. - М.. Мысль, 1991. $-478 \mathrm{c}$.

\section{ТЕОРЕТИЧЕСКИЕ АСПЕКТЫ ПОЗНАВАТЕЛЬНОЙ ДЕЯТЕЛЬНОСТИ}

Солдатенко Николай Николаевич, доктор педагогических наук, заведующий отдела теории и истории педагогического мастерства Института педагогического образования и образования для взрослых НАПН Украины, г. Киев

\section{Аннотация}

В статье анализируются некоторые особенности познавательного процесса, механизмы его взаимодействия с практической деятельностью и коммуникацией. Рассматривается учебное и научное познание, процессы развития знания и «производства» научного знания. Познавательная деятельность рассматривается как процесс получения нового знания через механизмы восприятия информации, её осмысления, запоминания и использования в практической деятельности. Анализируется характер взаимодействия нового знания с некоторыми компонентами социальной реальности, а также с тем знанием, которое ему предшествовало. 
Ключевые слова: познание, познавательный процесс, информация, научное знание.

\section{THEORETICAL ASPECTS OF COGNITIVE ACTIVITY}

Soldatenko M., Doctor of pedagogical sciences, Head of the Department of theory and history of pedagogical mastery of the Institute of Pedagogical Education and Education for the Adults of NAPS of Ukraine, Kyiv

\section{Resume}

The article deals with definite peculiarities of a cognitive activity, the mechanisms of its interconnection with practical activity and communication are analyzed. The learning and scientific cognition, the processes of the scientific knowledge development and creation are considered. The cognitive activity is regarded as the process of new knowledge acquisition by the mechanisms of perception of information, it's realizing, learning and using in practical activity. The character of interrelation of new knowledge with certain components of the social reality as well as with previous knowledge has been analyzed.

Keywords: knowledge, informative process, information, scientific knowledge.

Матеріал надійшов до редакції 26.02.2011 р. 